\title{
PENERIMAAN PANELIS DAN SIFAT KIMIAWI EMULSI LABU KUNING DAN FRAKSI OLEIN SAWIT
}

\author{
[Pannelists Acceptance and Chemical Properties of Pumpkin and \\ Palm Olein Fraction Emulsion]
}

\author{
Anton Rahmadi*, Yuliadini Puspita, Sukmiyati Agustin, dan Miftakhur Rohmah \\ Jurusan Teknologi Hasil Pertanian, Fakultas Pertanian, Universitas Mulawarman, Samarinda
}

Diterima 08 April 2015 / Disetujui 01 September 2015

\begin{abstract}
This study aimed to produce functional food products with the main ingredient of pumpkin and olein fraction of red palm oil (OF-RPO). This research was conducted in two stages. The first was to analyze consumer acceptance where a Completely Randomized Design was used with one factor. The factor was the composition of pumpkin and OF-RPO levelled as follow: 100:0, 95:5, 90:10, 85:15, 80:20, and 0:100 $(\mathrm{v} / \mathrm{V})$. In the second stage, analyses of carotenoids using HPLC, FFA, $p H$, vitamin $C$, and peroxide values were carried out on selected formula (mixture of pumpkin and OF-RPO), formula with $100 \mathrm{~mL}$ of pumpkin, formula with $100 \mathrm{~mL}$ of OF-RPO, and negative control (without pumpkin and OF-RPO), before and after the storage period of two months, except for HPLC analysis. The best formula based on acceptance test was a composition of $90 \mathrm{~mL}$ pumpkin and $10 \mathrm{~mL}$ OF-RPO was further diluted 1:4 (v/v). Characteristics of the product were sweet, sour, not bitter, not grassy, and not rancid. The emulsion product contains trans$\beta$-carotene at $141.65 \pm 0.47 \mathrm{mg} / \mathrm{L}$, equivalent to $237 \mathrm{UI}$ activity of vitamin $A / \mathrm{mL}$. The content of trans- $\beta$ carotene was found at the highest $(341.83 \mathrm{mg} / \mathrm{L})$ from the pumpkin juice, while the OF-RPO had the lowest trans- $\beta$-carotene content $(41.2 \mathrm{mg} / \mathrm{L})$. Product was acidic with a $\mathrm{pH}$ of $3.6 \pm 0.1$ and with vitamin $C$ content of $13.2 \pm 1.2 \mathrm{mg} / 100 \mathrm{~g}$ of product. Acidity and vitamin C levels tended to remain stable during the storage period for two months. Peroxide value of the emulsion product was at $0.8 \mathrm{mEq}$ oxygen $/ \mathrm{kg}$. The FFAs were in the range of 1.59 to $1.73 \%$ and they also did not change significantly after storage for two months.
\end{abstract}

Keywords: emulsification, pumpkin, red palm oil, $\beta$-carotene

\begin{abstract}
ABSTRAK
Penelitian ini bertujuan membuat produk emulsi pangan kaya karotenoid dengan bahan utama labu kuning dan fraksi olein dari minyak sawit merah (FO-MSM). Penelitian ini dilakukan dalam dua tahap. Tahap pertama ditunjukkan untuk menentukan formulasi terbaik berdasarkan penerimaan konsumen. Penelitian tahap ini dilakukan dengan Rancangan Acak Lengkap satu faktor. Faktor yang digunakan adalah komposisi labu kuning dan FO-MSM yaitu 100:0, 95:5, 90:10, 85:15, 80:20, dan 0:100 (v/v). Pada tahap selanjutnya, dilakukan analisis kimia yang terdiri dari analisis karoten menggunakan HPLC, asam lemak bebas, $\mathrm{pH}$, vitamin $\mathrm{C}$, dan bilangan peroksida. Analisis kimia dilakukan pada produk sari labu terpilih, produk dengan $100 \mathrm{~mL}$ labu kuning, produk dengan $100 \mathrm{~mL}$ FO-MSM, dan produk tanpa labu dan FO-MSM (kontrol) sebelum dan sesudah masa penyimpanan selama 2 bulan, kecuali untuk analisis HPLC. Panelis memilih satu produk terbaik yaitu komposisi $90 \mathrm{~mL}$ labu kuning dan $10 \mathrm{~mL}$ FO-MSM yang diencerkan 1:4 (v/v). Karakteristik produk adalah manis, asam, tidak pahit, tidak beraroma mentah, dan tidak beraroma tengik. Produk emulsi ters ebut memiliki kandungan trans $-\beta$-karoten sebesar 141,65 $\pm 0,47$ $\mathrm{mg} / \mathrm{L}$ atau setara dengan $237 \mathrm{UI}$ aktivitas vitamin A/mL. Kandungan trans- $\beta$-karoten tertinggi $(341,83$ $\mathrm{mg} / \mathrm{L})$ ada pada sari labu kuning, sementara MSM memiliki kandungan trans- $\beta$-karoten terendah $(41,2$ $\mathrm{mg} / \mathrm{L}$ ). Produk bersifat asam dengan $\mathrm{pH} 3,6 \pm 0,1$ dengan kandungan vitam in $\mathrm{C}$ sebesar $13,2 \pm 1,2 \mathrm{mg} / 100 \mathrm{~g}$ produk. Keasaman dan kadar vitamin $\mathrm{C}$ cenderung tetap stabil selama masa penyimpanan selama 2 bulan. Bilangan peroksida dari produk emulsi adalah $0,8 \mathrm{mEq}$ oksigen $/ \mathrm{kg}$ dan bilangan asam lemak bebas berada pada kisaran 1,59-1,73\%, juga tidak mengalami perubahan nyata setelah disimpan selama 2 bulan.
\end{abstract}

Kata kunci: emulsi, labu kuning, minyak sawit merah, $\beta$-karoten

*Penulis Korespondensi:

E-mail: arahmadi@unmul.ac.id 


\section{PENDAHULUAN}

Kekurangan vitamin A sudah diindikasikan terjadi di komunitas balita pada masyarakat Kalimatan Timur sejak dua dekade yang lalu berdasarkan hasil penelitian Setyahartini (1994). Pemerintah sebenarnya telah melakukan upaya perbaikan status gizi vitamin $A$ bagi balita dan ibu nifas. Penyediaan vitamin A dosis tinggi terbukti aman, murah, dan efisien dalam mencegah defisiensi vitamin A dan ketahanan balita (Sattar et al., 2012). Di Indonesia, berdasarkan data Departemen Kesehatan tahun 2009, sekalipun sekitar $90 \%$ balita telah mendapatkan kapsul vitamin A, cakupan program baru mencapai $60-75 \%$ untuk ibu nifas, sehingga masih perlu diupayakan dengan program lainnya. Pasca balita, vitamin A tetap perlu dikonsumsi oleh masyarakat. Ini berkaitan dengan pola konsumsi masyarakat yang kurang seimbang, mengingat $80 \%$ kebutuhan akan vitamin A dipengaruhi oleh diversifikasi makanan yang dikonsumsi (Benn et al., 2008). Intervensi vitamin A perlu dilakukan utamanya di daerah pedesaan yang asupan gizinya tidak imbang disebabkan oleh kemiskinan atau keterbelakangan.

Labu kuning (Cucurbita moschata) dan minyak sawit merah (MSM) merupakan produk unggulan di Indonesia dan kaya akan karotenoid. Secara terpisah, kedua bahan ini telah diujicobakan untuk perbaikan status gizi vitamin A di Indonesia. Kedua bahan baku ini secara terpisah terbukti mampu meningkatkan serum $\beta$-karoten di dalam darah. Serum $\beta$-karoten balita di Kalimantan timur setelah intervensi vitamin A menurut Setyahartini (1994) meningkat sebesar $30-80 \mu \mathrm{g} / \mathrm{dL}$ setelah balita mengonsumsi daging buah labu kuning setara 250$400 \mu \mathrm{g}$ retinol. Diketahui kadar serum ibu untuk $\beta$ karoten dan $\alpha$-karoten meningkat dua kali setelah intervensi dengan MSM selama 10 hari pada konsentrasi $90 \mathrm{mg}$ setara $\beta$-karoten dalam konsumsinya. Setelah mengonsumsi diet kaya karotenoid, terdapat peningkatan serum retinil palmitat yang merupakan hasil reaksi antara asam palmitat dan retinil asetat. Observasi ini didapat pula pada retinil stearat, retinil oleat, dan retinil linoleat, yang menunjukkan bahwa setelah 6 jam, tubuh membentuk retinil ester (Oxley et al., 2014). Konsentrasi $\alpha$ - dan $\beta$-karoten dari minyak sawit yang diperoleh adalah minimum 506 ppm (Jaswir et al., 2011). MSM merupakan sumber tertinggi karotenoid, akan tetapi memiliki palatabilitas yang kurang disukai apabila dikonsumsi tanpa dikombinasi dengan bahan lain. Jacobo-Valenzuela et al. $\left(2011^{\mathrm{a}}\right) \mathrm{me}-$ nyebutkan kandungan dari $C$. moschata, yaitu serat $19,1 \%$, pektin $7,3 \%$, dan karotenoid $2,7 \mathrm{mg} \beta$ karoten $/ g$ buah. Penggunaan gabungan labu dan fraksi olein dari minyak sawit merah (FO-MSM) dilakukan sebagai salah satu strategi peningkatan penerimaan konsumen terhadap suplemen vitamin A asal bahan lokal. Perpaduan dua bahan baku, FOMSM dan labu kuning, diharapkan mampu menjadi alternatif produk berkonten lokal untuk intervensi vitamin A. $\beta$-karoten merupakan salah satu prekursor vitamin $A$, dicirikan dengan cincin $\beta$-ionon (Groeber, 2013). Peranan karotenoid terhadap kesehatan mata misalnya terdapat pada mesozeaxanthin yang efektif dalam menjaga makula mata dari proses oksidasi (Firdous et al., 2010). Selain itu, lutein, likopen, zeaxanthin, cryptoxanthin, dan akaroten juga merupakan karotenoid penting (Tang, 2012). Kegunaan diet kaya karotenoid tidak sebatas normalisasi kadar serum karotenoid. Vaisman et al. (2006) menyebutkan bahwa diet kaya karotenoid dalam jangka panjang juga menurunkan stress oksidatif dari konsumennya. Dalam hal ini, konsentrasi NF-KB pasien cenderung turun setelah mengonsumsi diet kaya karotenoid.

Penelitian ini bertujuan untuk membuat produk emulsi pangan fungsional kaya karotenoid dengan bahan utama ekstrak labu kuning dan fraksi olein (FO)-MSM. Diharapkan, penelitian ini merupakan awal dari proses menuju suplemen vitamin A terstandar dengan bahan baku lokal dari labu kuning dan FO-MSM bagi balita kurang vitamin $\mathrm{A}$.

\section{BAHAN DAN METODE}

\section{Bahan}

Bahan baku labu kuning diperoleh pada bulan April-September 2014 dari pedagang pengumpul dan pasar tradisional di sekitar Samarinda, Kalimantan Timur. CPO sebagai bahan FO-MSM diperoleh dari pabrik Crude Palm Oil (CPO) di sekitar Samarinda, Kalimantan Timur. Bahan pangan pembantu lain dibeli dari toko bahan roti dan kue setempat.

\section{Pembuatan sari labu kuning}

Metode pembuatan sari labu kuning dikembangkan oleh Rahmadi et al. (2014). Buah labu kuning segar (berat $\pm 2 \mathrm{~kg}$ ) dikupas kulitnya dan diambil daging buahnya. Daging buah labu kuning selanjutnya dipotong-potong dengan ukuran $\pm 3-5$ $\mathrm{cm}^{3}$ dan dicuci di bawah air mengalir hingga bersih. Potongan daging buah labu kuning dimasukkan ke dalam juicer untuk menghasilkan sari buah labu kuning. Sari buah yang diperoleh kemudian dipasteurisasi pada suhu $80^{\circ} \mathrm{C}$ selama 10 menit dan disaring menggunakan kain saring bersih. Sari labu kuning yang diperoleh selanjutnya ditempatkan dalam wadah kontainer plastik tertutup dan disimpan dalam lemari pendingin sebelum digunakan. 


\section{Pembuatan FO-MSM dari CPO}

Metode pembuatan FO-MSM dari CPO mengacu Rahmadi et al. (2014). Sebanyak $300 \mathrm{~mL}$ CPO dimasukkan dalam labu kocok kapasitas 500 $\mathrm{mL}$. Ditambahkan $100 \mathrm{~mL}$ air hangat (suhu $80-90^{\circ} \mathrm{C}$ ) ke dalam labu kocok tersebut dan dilakukan pengocokan selama 1 menit. Setelah dilakukan pengocokan terdapat dua fasa, fasa air pada bagian bawah labu kocok dan fasa minyak pada bagian atas. Fasa air dikeluarkan dari labu kocok dan dibuang. Ke dalam fasa minyak yang tersisa di dalam labu kocok ditambahkan larutan $10 \% \mathrm{NaOH}$ (Sigma, Singapore) sebanyak $400 \mu \mathrm{L}$ dan dikocok selama 1 menit. Fasa air dikeluarkan dari labu kocok dan dibuang. Dilakukan pembilasan dengan cara menambahkan $50 \mathrm{~mL}$ air hangat (suhu $80-90^{\circ} \mathrm{C}$ ). Fasa air dikeluarkan dan dibuang. Dilakukan uji bebas basa dengan menggunakan kertas lakmus. Bila kertas lakmus menunjukkan warna biru, pembilasan kembali dengan $50 \mathrm{~mL}$ air hangat dengan suhu $90^{\circ} \mathrm{C}$ hingga bebas basa. Fraksi minyak yang sudah bebas basa didiamkan semalam sehingga terbentuk dua fasa: fasa padatan (stearin) dan fasa cairan (olein). Fasa cairan dipisahkan dari fasa padatan. Proses fraksinasi ini dilakukan sebanyak dua kali. Fasa cairan (FO-MSM) dipanaskan menggunakan Rotavapor R-II (Buchi, Swiss) pada kondisi $100^{\circ} \mathrm{C}, 60 \mathrm{rpm}, 80-90 \mathrm{mmHg}$ selama $5 \mathrm{jam}$. FOMSM ditempatkan dalam botol kaca gelap bertutup dan disimpan dalam lemari pendingin sebelum digunakan.

\section{Pembuatan produk emulsi sari labu kuning dan FO-MSM}

Metode pembuatan produk emulsi sari labu kuning dan FO-MSM dikembangkan oleh Rahmadi et al. (2014). Pembuatan emulsi dilakukan dengan mencampurkan sari labu kuning dengan FO-MSM. Untuk menstabilkan emulsi digunakan carboxymethylcellulose (CMC) dan guar gum. Sari labu kuning dan FO-MSM dicampur dengan perbandingan tertentu (volume total campuran $100 \mathrm{~mL}$ ). CMC food grade komersial $2 \%(\mathrm{~b} / \mathrm{v})$, gum guar food grade komersial $2 \%(\mathrm{~b} / \mathrm{v})$, bubuk kayu manis food grade komersial $0,5 \%$ (b/v) ditambahkan pada campuran dan dihomogenkan. Air bersih layak minum (suhu hangat berkisar $80-90^{\circ} \mathrm{C}$ ) ditambahkan sehingga volume akhir campuran menjadi $500 \mathrm{~mL}$. Pemanis sirup fruktosa $5 \%(\mathrm{v} / \mathrm{v})$, asam sitrat food grade komersial $0,5 \%(\mathrm{~b} / \mathrm{v})$ dan perasa jeruk (food grade) komersial $0,5 \%(\mathrm{v} / \mathrm{v})$ ditambahkan pada campuran untuk selanjutnya dihomogenkan dengan blender (kecepatan rendah, 3 menit). Emulsi disaring dan ditempatkan dalam kemasan botol kaca gelap bertutup. Botol berisi produk emulsi kemudian dipasteurisasi pada suhu $70^{\circ} \mathrm{C}$ selama 15 menit. Dari hasil penelitian pendahuluan, didapatkan bahwa emulsi tetap dalam kondisi stabil setelah disimpan selama satu bulan dalam suhu ruang $\left(25-30^{\circ} \mathrm{C}\right)$.

\section{Uji penerimaan dan preferensi panelis}

Penelitian ini dilaksanakan menggunakan faktor tunggal yaitu konsentrasi sari labu kuning dan FOMSM dalam emulsi. Terdapat tujuh taraf perbandingan sari labu kuning terhadap FO-MSM sebelum pengenceran yaitu TO $=0: 0$ (volume sari labu kuning:volume FO-MSM) sebagai kontrol, T1= $0: 100, \mathrm{~T} 2=95: 5, \mathrm{~T} 3=90: 10, \mathrm{~T} 4=85: 15, \mathrm{~T} 5=80: 20$, $\mathrm{T} 6=100: 0(\mathrm{v} / \mathrm{v})$.

Uji penerimaan dan preferensi menggunakan metode Montenegro et al. (2015). Uji penerimaan dan preferensi digunakan untuk mengetahui penerimaan panelis terhadap ketujuh formulasi emulsi sarilabu kuning dan FO-MSM. Pada uji penerimaan, sebanyak 30 panelis tidak terlatih dengan rentang usia 17-21 tahun diminta penilaiannya terhadap parameter penerimaan pada rasa, aroma, tekstur, warna, dan penerimaan keseluruhan. Uji preferensi, juga dengan 30 orang panelis, dilakukan terhadap parameter palatabilitas yang terdiri dari rasa manis, asam, dan pahit, serta aroma mentah dan tengik. Angka yang diperoleh kemudian ditransformasikan dalam skala yaitu: satu (1) untuk sangat tidak terasa, dua (2) untuk tidak terasa, tiga (3) untuk netral, empat (4) untuk terasa, dan lima (5) untuk sangat terasa. Juga dilakukan uji hedonik untuk menentukan penerimaan panelis terhadap warna, rasa, aroma, tekstur, dan penerimaan keseluruhan. Angka yang diperoleh kemudian ditransformasikan dalam skala yaitu: satu (1) untuk sangat tidak disukai, dua (2) untuk tidak disukai, tiga (3) untuk netral, empat (4) untuk disukai, dan lima (5) untuk sangat disukai. Data yang diperoleh dianalisis dengan GraphPad Prism 6. Jika terdapat pengaruh yang berbeda nyata pada taraf a $5 \%$ pada sidik ragam, maka dilakukan uji lanjut dengan Dunnet multiple comparisons test. Sebagai pembanding adalah formulasi dengan $100 \%$ FO-MSM.

\section{Analisis B-karoten}

Sampel emulsi sari labu kuning dan FO-MSM dipersiapkan segar dan kemudian disimpan pada suhu $4^{\circ} \mathrm{C}$ tidak lebih dari tujuh hari sebelum analisis. Total karotenoid diuji menggunakan menggunakan instrumen HPLC (Simadzu LC20AD, Japan) dengan kolom C-18, dan detektor UV-Vis (Shimadzu, Japan) pada panjang gelombang $450 \mathrm{~nm}$. Pengujian dilakukan di laboratorium SEAFAST, IPB.

Preparasi dilakukan dengan mengambil sebanyak 3 gram sampel untuk ditimbang dan dimasukkan ke dalam labu erlenmeyer dan ditambahkan kloroform (Merck) - methanol (Merck) (2:1) sebanyak $20 \mathrm{~mL}$. Selanjutnya, larutan diaduk dengan bantuan stirrer selama 1 jam dan disaring. Larutan kemudian ditambahkan $4 \mathrm{~mL} 0,88 \% \mathrm{NaCl}$ 
(Merck) dan kemudian dikocok. Setelah terbentuk dua lapisan, lapisan atas dibuang dan lapisan bawah disaring menggunakan kertas saring. Larutan kemudian dievaporasi dan dihembus gas $\mathrm{N}_{2}$. Ekstrak minyak ditempatkan di dalam botol gelap dan disimpan di dalam refrigerator sampai dibutuhkan untuk dianalisis. Apabila ekstrak minyak akan dianalisis, maka terlebih dahulu minyak dipindahkan dari tempat penyimpanan, didiamkan pada suhu ruang sampai semuanya meleleh.

Kadar $\beta$-karoten dalam sampel ditentukan dengan metode AOAC Official Method 2001.13 (AOAC, 2005). Sampel sebanyak 0,1-0,25 g disaponifikasi menggunakan $10 \mathrm{~mL}$ etanol absolut (Merck) dan 2,5 mL KOH (Merck) 50\% dalam aquades (b/v), kemudian dipanaskan dalam penangas air bersuhu $80^{\circ} \mathrm{C}$ selama 1 jam. Campuran didinginkan dan ditambah 2,5 $\mathrm{mL}$ asam asetat glasial (Merck). Campuran dipindahkan ke dalam labu ukur $25 \mathrm{~mL}$ dan volume ditepatkan dengan ethanol: tetrahydrofuran (Merck) 1:1 (v/v). Kemudian sampel disaring dengan filter syringe polyvinylidene fluoride (PVDF) berukuran pori 0,45 $\mu \mathrm{m}$ (Milipore). Kadar $\beta$ karoten ditentukan dengan HPLC (Shimadzu, Jepang) secara isokratik menggunakan kolom $\mathrm{C} 18$ atau ODS $(15 \mathrm{~cm} \times 4,6 \mathrm{~cm}$, i.d. $5 \mu \mathrm{m})$ dan detektor UV Vis pada $450 \mathrm{~nm}$. Elusi dilakukan dengan laju alir $1,0 \mathrm{~mL} /$ menit pada suhu ruang, menggunakan fase gerak metil diklorida/metanol/asetonitril (Merck) $(2: 1: 3)$ yang telah disonikasi selama 45 menit. Puncak $\beta$-karoten dalam sampel diidentifikasi dengan mencocokkan waktu retensi peak $\beta$-karoten dalam sampel dengan waktu retensi standar $\beta$ karoten.

\section{Analisis uji pH}

Uji $\mathrm{pH}$ dilakukan menggunakan $\mathrm{pH}$ meter komersial dengan mengambil contoh produk sebanyak $\pm 50 \mathrm{~mL}$ ke dalam sebuah gelas piala dan kemudian $\mathrm{pH}$ diukur sebanyak dua kali (duplo) untuk setiap ulangan produk.

\section{Uji vitamin C, Peroxide Value (PV) dan Free Fatty Acid (FFA)}

Metode Sudarmadji et al. (2003) digunakan untuk analisa kadar vitamin $\mathrm{C}$, uji PV, dan uji FFA. Dalam perhitungan FFA, berat molekul yang digunakan untuk produk FO-MSM adalah $256 \mathrm{~g} / \mathrm{mol}$ tetapi untuk produk emulsi, labu kuning, dan kontrol (tanpa labu dan FO-MSM) adalah $278 \mathrm{~g} / \mathrm{mol}$.

\section{HASIL DAN PEMBAHASAN}

\section{Penerimaan dan preferensi konsumen}

FO-MSM memiliki potensi kandungan vitamin A yang sangat tinggi dalam bentuk provitamin $A$, yaitu 20,000 $\mu \mathrm{g}$ ekuivalen retinol $(\mathrm{RE}) / 100 \mathrm{~g}$, diban- dingkan dengan labu kuning yang hanya 2,217 $\mu \mathrm{gRE} / 100 \mathrm{~g}$ (USDA, 2014). Sebagai bahan baku, CPO diperlukan dalam kondisi prima, yaitu yang memiliki FFA <3\%. Dalam pembuatan produk pangan fungsional kaya karotenoid selainkadar karotenoid yang sangat tinggi, diperlukan juga komposisi karotenoid yang lengkap dan produk yang dapat diterima oleh konsumen (Tadmor et al., 2005). Produk kaya akan karotenoid bersumber dari FOMSM, misalnya, telah dikembangkan oleh Wulandari (2000). Akan tetapi, berdasarkan formulasi emulsi yang dilakukan pada penelitian ini, formula dengan $100 \%$ FO-MSM memiliki masalah dalam penerimaan konsumen yang rendah terkait rasa, aroma, dan tekstur yang kurang disukai konsumen (Gambar 1 s.d. 4). Selain itu, perubahan struktur $\beta$-karoten dari FO-MSM pasca pemanasan selama lima jam menyebabkan komposisi karotenoid dari FO-MSM berubah (Gambar 11).

Penciptaan produk pangan fungsional kaya karotenoid, terdapat hubungan yang erat antara keberadaan berbagai jenis karotenoid dengan peningkatan sistem imun tubuh (Sepp et al., 2010). Status karotenoid yang baik menurut Groeber (2013) adalah $\beta$-karoten lebih dari 0,4 $\mu \mathrm{mol} / \mathrm{L}$ (21 $\mu \mathrm{g} / \mathrm{dL}$ ), likopen lebih dari $0,5 \mu \mathrm{mol} / \mathrm{L}$, lutein lebih dari $0,6 \mu \mathrm{mol} / \mathrm{L}$. Diet kaya karotenoid dengan komposisi trans- $\beta$-karoten, $\beta$-kriptosantin, lutein, dan $\alpha$-karoten dapat mengurangi risiko penyakit degeneratif seperti katarak, degenerasi makula, dan beberapa jenis karsinoma (Rao dan Rao, 2007). Untuk itu, dalam upaya perbaikan komposisi karotenoid dan rasa dari produk, perlu dilakukan penggabungan dua jenis produk kaya karotenoid ini untuk menghasilkan produk dengan kualitas yang dapat diterima konsumen dengan lebih baik.

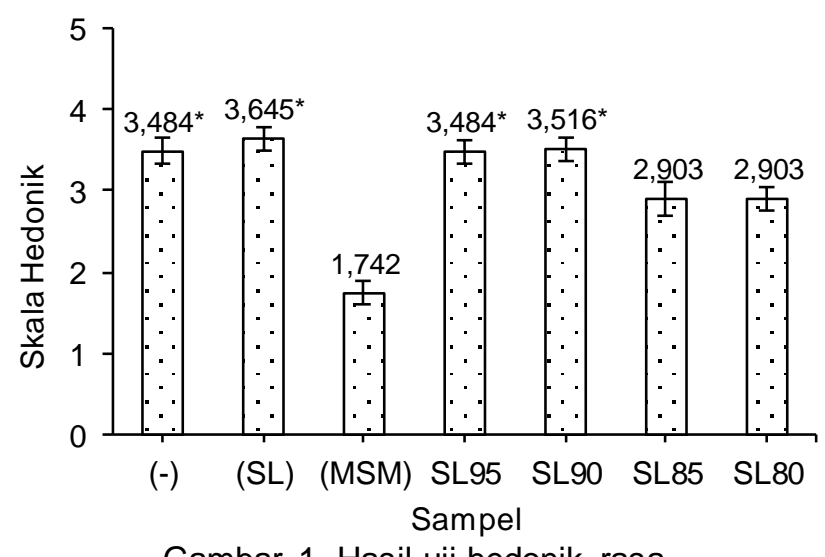

Gambar 1. Hasil uji hedonik rasa

Keterangan: Produk memiliki formula sebagai berikut: $(-)=$ kontrol (tanpa sari labu kuning dan FO-MSM), SL = sari labu kuning $100 \mathrm{~mL}$, FO-MSM = minyak sawit merah $100 \mathrm{~mL}$, SL95 = sari labu kuning 95, SL90 = 90, $\mathrm{SL85}=85$, SL80 $=80$. Standard Error of the Mean (SEM) ditampilkan dengan simbol $(T$ ) yang terletak di atas batang diagram. Simbol * dan ** menandakan kelompok yang berbeda nyata 
Gambar 1 menjelaskan hasil uji hedonik rasa, yang menunjukkan kontrol dan formula dengan 90$100 \mathrm{~mL}$ sari labu kuning mendapat tingkat penerimaan rasa yang sama. Emulsi dengan formula $100 \mathrm{~mL}$ FO-MSM mendapatkan penerimaan rasa yang paling rendah. Terhadap parameter aroma (Gambar 2), penerimaan terhadap kontrol dan formula dengan $100 \mathrm{~mL}$ sari labu kuning secara signifikan $(P<0,05)$ paling tinggi dibandingkan formula yang lain. Formula dibuat dari proporsi 80, 90, dan $95 \mathrm{~mL}$ sari labu kuning terhadap 20, 10, dan 5 mL FO-MSM memiliki penerimaan terhadap aroma yang sama dan berbeda secara signifikan jika dibandingkan dengan formula $100 \mathrm{~mL}$ FO-MSM. Ini sejalan dengan hasil penelitian Wulandari (2000) yang menyatakan bahwa produk dengan bahan baku MSM cenderung mendapatkan penerimaan terhadap rasa dan aroma yang rendah.

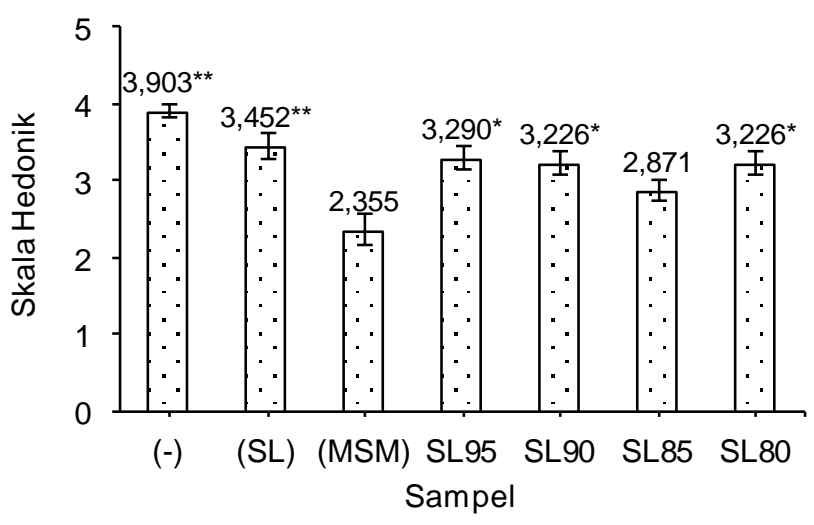

Gambar 2. Hasil uji hedonik aroma

Keterangan:Produk memiliki formula sebagai berikut: $(-)=$ kontrol (tanpa sari labu kuning dan FO-MSM), SL = sari labu kuning $100 \mathrm{~mL}$, FO-MSM = minyak sawit merah $100 \mathrm{~mL}, \mathrm{SL95}=$ sari labu kuning 95, SL90 = 90, SL85 $=85$, SL80 = 80. SEM ditampilkan dengan simbol ( $T$ ) yang terletak di atas batang diagram. Simbol * dan ** menandakan kelompok yang berbeda nyata

Berkaitan dengan tekstur produk (Gambar 3), formula dengan $100 \mathrm{~mL}$ FO-MSM menunjukkan hasil yang paling rendah secara signifikan $(P<0,05)$ jika dibandingkan dengan formula yang lain. Parameter uji organoleptik yang lain adalah warna (Gambar 4), yang menunjukkan bahwa formula dengan $100 \mathrm{~mL}$ sari labu kuning, 90 dan $95 \mathrm{~mL}$ sari labu kuning terhadap 10 dan $5 \mathrm{~mL}$ FO-MSM menghasilkan tekstur yang lebih diterima oleh konsumen dibandingkan semua formula yang lain. Formula dengan $100 \mathrm{~mL}$ FO-MSM juga secara signifikan $(P<$ $0,05)$ menghasilkan penerimaan yang paling rendah dibandingkan seluruh jenis formula yang diujikan. Secara keseluruhan, formula dengan $100 \mathrm{~mL}$ FOMSM mendapatkan penerimaan yang paling rendah jika dibandingkan dengan formula-formula yang diujikan. Formula-formula yang mendapatkan penerimaan konsumen terbaik secara signifikan adalah kontrol, formula dengan $100 \mathrm{~mL}$ sari labu kuning, formula 95:5, 90:10, dan 80:20 (sari labu kuning:FOMSM) (Gambar 5).

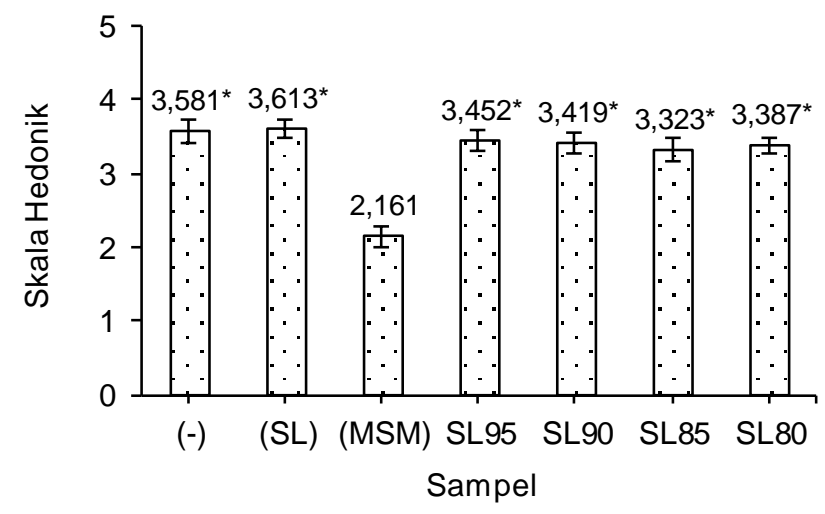

Gambar 3. Hasil uji hedonik tekstur

Keterangan: Produkmemiliki formula sebagai berikut: $(-)=$ kontrol (tanpa sari labu kuning dan FO-MSM), SL = sari labu kuning $100 \mathrm{~mL}$, FO-MSM = minyak sawit merah $100 \mathrm{~mL}, \mathrm{SL} 95=$ sari labu kuning $95, \mathrm{SL} 90=90$, SL85 $=85$, SL80 $=80$. SEM ditampilkan dengan simbol ( $T$ ) yang terletak di atas batang diagram. Simbol * dan ${ }^{* *}$ menandakan kelompok yang berbeda nyata

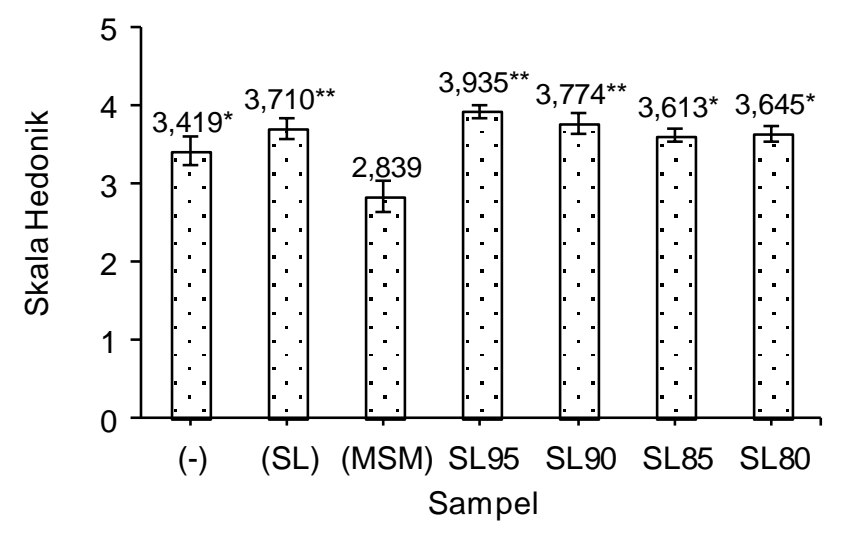

Gambar 4. Hasil uji hedonik warna

Keterangan: Produk memiliki formula sebagai berikut: $(-)=$ kontrol (tanpa sari labu kuning dan FO-MSM), SL = sari labu kuning $100 \mathrm{~mL}$, FO-MSM = minyak sawit merah $100 \mathrm{~mL}$, SL95 = sari labu kuning 95, SL90 = 90, SL85 = 85, SL80 = 80. SEM ditampilkan dengan simbol ( $T$ ) yang terletak di atas batang diagram. Simbol * dan ** menandakan kelompok yang berbeda nyata

Pengembangan produk baru diperlukan penekanan pada parameter sensoris yang pentingdan menentukan penerimaan produk tersebut. Sebagai contoh, Konopacka et al. (2010) mengemukakan bahwa produk olahan labu dengan total karotenoid 
tertinggi belum tentu dipilih oleh konsumen oleh sebab penerimaan sensoris secara keseluruhan yang rendah.

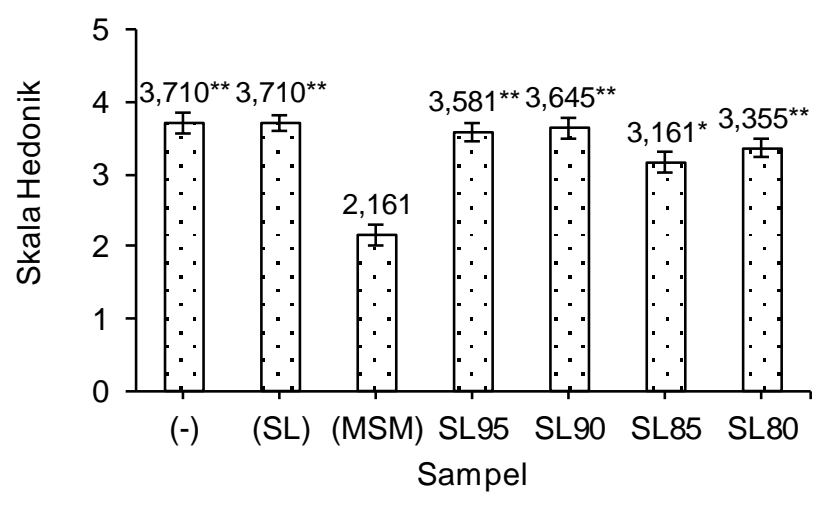

Gambar 5. Hasil uji hedonik keseluruhan

Keterangan: Produk memiliki formula sebagai berikut: $(-)=$ kontrol (tanpa sari labu kuning dan FO-MSM), SL = sari labu kuning $100 \mathrm{~mL}$, FO-MSM = minyak sawit merah $100 \mathrm{~mL}$, SL95 = sari labu kuning 95, SL90 = 90, SL85 $=85$, SL80 = 80. SEM ditampilkan dengan simbol $(T)$ yang terletak di atas batang diagram. Simbol * dan ** menandakan kelompok yang berbeda nyata

Goncalves et al. (2007) mengemukakan bahwa tekstur dalam emulsi dipengaruhi oleh keberadaan senyawa seperti pektin. Salah satu strategi yang digunakan untuk meningkatkan penerimaan terhadap rasa dari sari labu adalah pasteurisasi pada suhu $72^{\circ} \mathrm{C}$ selama 2 menit (Jacobo-Valenzuela et al., 2011 ${ }^{\mathrm{b}}$ ). Berkaitan dengan penelitian ini, komposisi sari labu kuning $\geq 90 \mathrm{~mL}$ dalam emulsi memberikan pengaruh yang lebih baik terhadap penerimaan konsumen pada parameter tekstur dibandingkan emulsi dengan komposisi sari labu yang lebih rendah. Akan tetapi, secara umum, konsumen lebih memilih produk dengan komposisi $100 \mathrm{~mL}$ labu kuning. Dari hasil tersebut, didapatkan kesimpulan bahwa panelis dalam penelitian ini tidak mampu membedakan formulasi sari labu kuning:FOMSM (95:5) dari formulasi (90:10) (v/v). Pada saat menaikkan komposisi FO-MSM menjadi $\geq 15 \mathrm{~mL}$, terdapat penurunan penerimaan konsumen terhadap produk emulsi terutama pada parameter rasa dan aroma. Komposisi produk emulsi terbaik dengan potensi kandungan karotenoid tertinggi diperoleh dari formulasi sari labu kuning:FO-MSM (90:10) $(\mathrm{v} / \mathrm{v})$.

Hasil uji untuk parameter kesukaan terhadap rasa manis, asam, dan pahit, serta aroma mentah dan tengik, diperoleh hasil bahwa produk formulasi yang diteliti berasa manis, netral hingga asam, netral hingga tidak pahit, aroma mentah cenderung netral, dan aroma tengik yang tidak tercium (Gambar 6-10). Pengecualian terdapat pada formulasi dengan $100 \mathrm{~mL}$ FO-MSM yang menghasil- kan preferensi yang paling buruk dibandingkan dengan formula yang lain.

\section{Kadar karotenoid}

Dikarenakan keterbatasan standar, maka hanya dilakukan perhitungan berdasarkan kandungan trans- $\beta$-karoten. Hasil analisis menunjukkan sari labu kuning memiliki kadar trans- $\beta$-karoten sebesar $341,83 \pm 1,20 \mathrm{mg} / \mathrm{L}$ produk. FO-MSM memiliki kandungan trans- $\beta$-karoten terendah diantara ketiga produk yang diujikan, yaitu $41,18 \pm 0,10 \mathrm{mg} / \mathrm{L}$, sementara produk emulsi memiliki kadar trans- $\beta$ karoten sebesar 141,65 $\pm 0,47 \mathrm{mg} / \mathrm{L}$. Hasil analisis total karotenoid dengan metode HPLC memberikan hasil rata-rata $142 \mathrm{mg}$ setara trans $\beta$-karoten/L. Berdasarkan Groeber (2013), pengukuran aktivitas vitamin A sebanyak 1 UI dapat diperoleh dengan konversi sebanyak $0,6 \mu \mathrm{g} \beta$-karoten, sehingga pada formula terpilih didapatkan kandungan vitamin $A$ sebesar $237 \mathrm{UI} / \mathrm{mL}$ produk.

\section{Lutein dan xantin}

Salah satu hasil lain yang menarik untuk dibahas adalah keberadaan puncak sempit namun sangat tinggi dari produk dengan komposisi $100 \mathrm{~mL}$ sari labu kuning dan emulsi $90 \mathrm{~mL}$ sari labu kuning terhadap $10 \mathrm{~mL}$ FO-MSM pada kisaran waktu retensi 1,675-1,843 menit (Gambar 13). Puncak tersebut diduga adalah lutein dan zeaxanthin. Karakter produk ini sejalan dengan hasil Badr et al. (2011) yang menyatakan labu dengan warna kuning-merah dibentuk oleh tiga karotenoid utama, yaitu $\beta$-karoten, $\alpha$-karoten, dan lutein. Oleh karena itu, dapat dimungkinkan bahwa berdasarkan kromatogram dari produk emulsi, komponen karotenoid didominasi oleh lutein, xanthin, trans- $\beta$-karoten dan cis- $\beta$-karoten.

\section{Efek pemanasan terhadap kadar dan komposisi karotenoid}

Stabilitas $\beta$-karoten sangat dipengaruhi oleh isomerasi dan reaksi oksidasi yang terjadi selama pengolahan dan penyimpanan produk (Gliemmo et al., 2009). Faktor yang berpengaruh terhadap pengolahan adalah suhu, cahaya, keberadaan oksigen, logam, enzim, lipida tidak jenuh, dan prooksidan yang mungkin ditambahkan (Schieber dan Carle, 2005).

Hal yang menarik terdapat pada kromatogram dari produk FO-MSM yang menunjukkan sedikit kandungan trans- $\beta$-karoten dibandingkan dengan cis- $\beta$-karoten (Gambar 11). Untuk mengurangi aroma khas minyak sawit yang menyengat dari FOMSM, telah dilakukan pemanasan FO-MSM dalam waktu yang cukup lama (suhu $100^{\circ} \mathrm{C}$, kecepatan rotasi $60 \mathrm{rpm}$, tekanan $80-90 \mathrm{mmHg}$, waktu 5 jam), sehingga diduga berpengaruh terhadap perubahan komposisi cis- dan trans- $\beta$-karoten dari FO-MSM. 


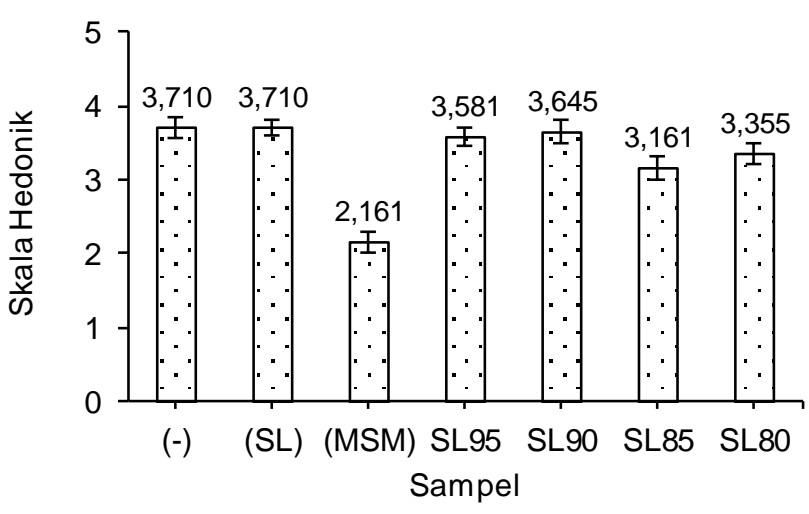

Gambar 6. Hasil uji preferensi rasa manis

Keterangan: Produk memiliki formula sebagai berikut: $(-)=$ kontrol (tanpa sari labu kuning dan FO-MSM), SL = sari labu kuning $100 \mathrm{~mL}$, FO-MSM = minyak sawit merah $100 \mathrm{~mL}$, SL95 = sari labu kuning 95, SL90 = 90, SL85 $=85$, SL80 $=80$. SEM ditampilkan dengan simbol $(T)$ yang terletak di atas batang diagram

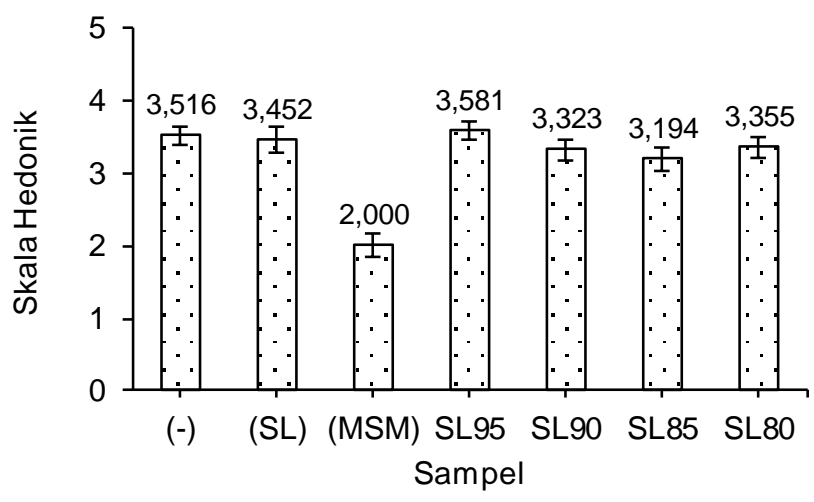

Gambar 7. Hasil uji preferensi rasa asam

Keterangan: Produk memiliki formula sebagai berikut: $(-)=$ kontrol (tanpa sari labu kuning dan FO-MSM), SL = sari labu kuning $100 \mathrm{~mL}$, FO-MSM = minyak sawit merah $100 \mathrm{~mL}$, SL95 = sari labu kuning 95, SL90 = 90, SL85 $=85$, SL80 $=80$. SEM ditampilkan dengan simbol $(T)$ yang terletak di atas batang diagram

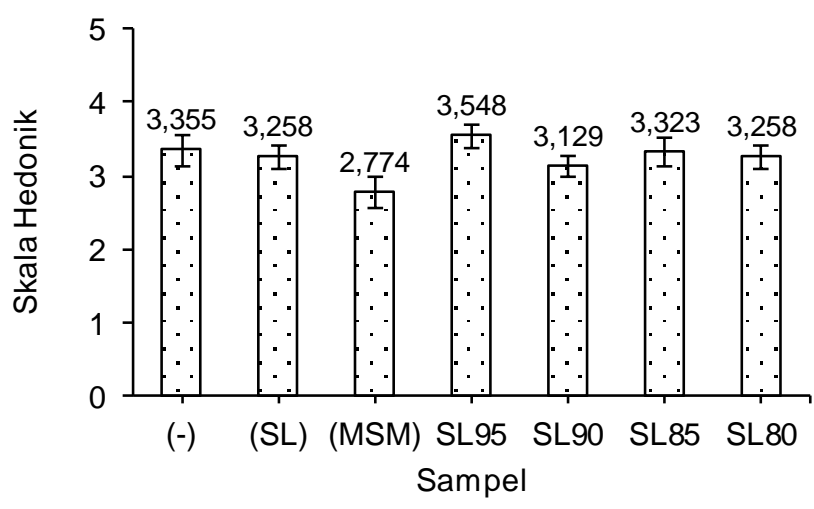

Gambar 8. Hasil uji preferensi rasa pahit

Keterangan: Produk memiliki formula sebagai berikut: $(-)=$ kontrol (tanpa sari labu kuning dan FO-MSM), SL = sari labu kuning $100 \mathrm{~mL}$, FO-MSM = minyak sawit merah $100 \mathrm{~mL}$, SL95 = sari labu kuning 95, SL90 = 90, SL85 $=85$, SL80 $=80$. SEM ditampilkan dengan simbol ( $T$ ) yang terletak di atas batang diagram

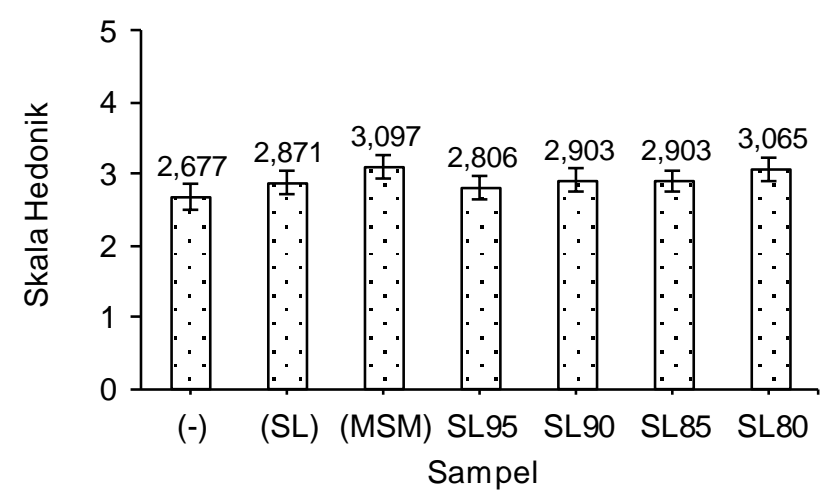

Gambar 9. Hasil uji preferensi aroma mentah

Keterangan: Produk memiliki formula sebagai berikut: $(-)=$ kontrol (tanpa sari labu kuning dan FO-MSM), SL = sari labu kuning $100 \mathrm{~mL}$, FO-MSM = minyak sawit merah $100 \mathrm{~mL}$, SL95 = sari labu kuning 95, SL90 = 90, SL85 $=85$, SL80 $=80$. SEM ditampilkan dengan simbol $(T)$ yang terletak di atas batang diagram

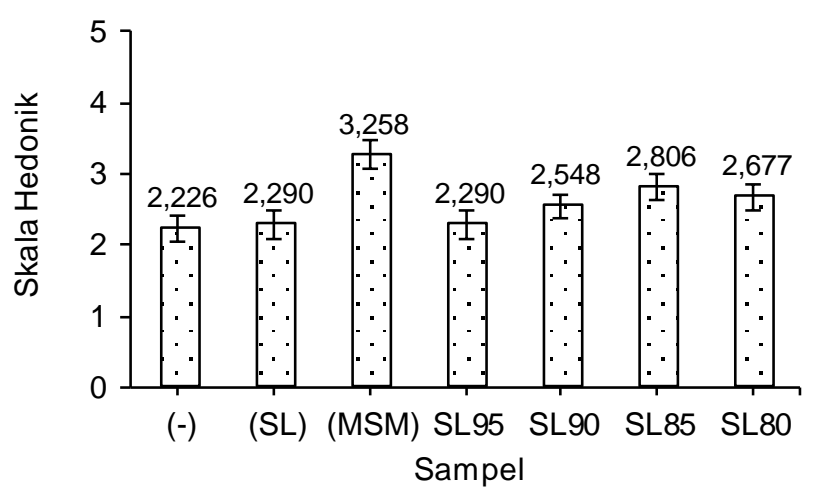

Gambar 10. Hasil uji preferensi aroma tengik

Keterangan: Produk memiliki formula sebagai berikut: $(-)=$ kontrol (tanpa sari labu kuning dan FO-MSM), SL = sari labu kuning $100 \mathrm{~mL}$, FO-MSM = minyak sawit merah $100 \mathrm{~mL}, \mathrm{SL} 95=$ sari labu kuning 95, SL90 = 90, SL85 $=85$, SL80 $=80$. SEM ditampilkan dengan simbol $(T)$ yang terletak di atas batang diagram

Komposisi trans- $\beta$-karoten sari labu setelah dipasteurisasi (suhu $80^{\circ} \mathrm{C}$ selama 10 menit) masih terlihat dominan (Gambar 12). Perubahan yang sama juga tampak pada produk dengan komposisi $90 \mathrm{~mL}$ sari labu kuning dan $10 \mathrm{~mL}$ FO-MSM (Gambar 13). Ini dikarenakan perlakuan panas yang diberikan tidak sebagaimana halnya proses pemanasan FO-MSM. Berdasarkan literatur, pemasakan labu meningkatkan kadar cis- $\beta$-karoten dari tidak terdeteksi menjadi $0,7 \mu \mathrm{g} / \mathrm{g}$, dan terus semakin meningkat seiring proses pemanasan yang diberikan (Provesi et al., 2011). 


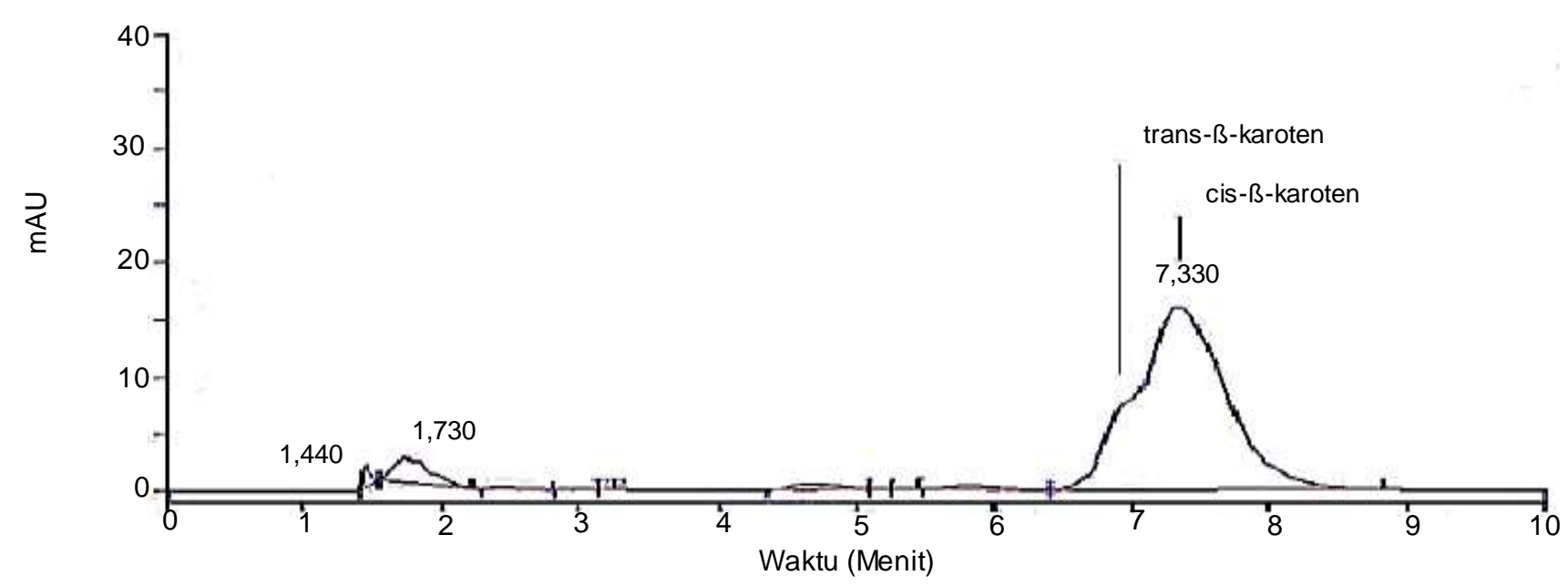

Gambar 11. Kromatogram karotenoid dari produk dengan FO-MSM $100 \mathrm{~mL}$

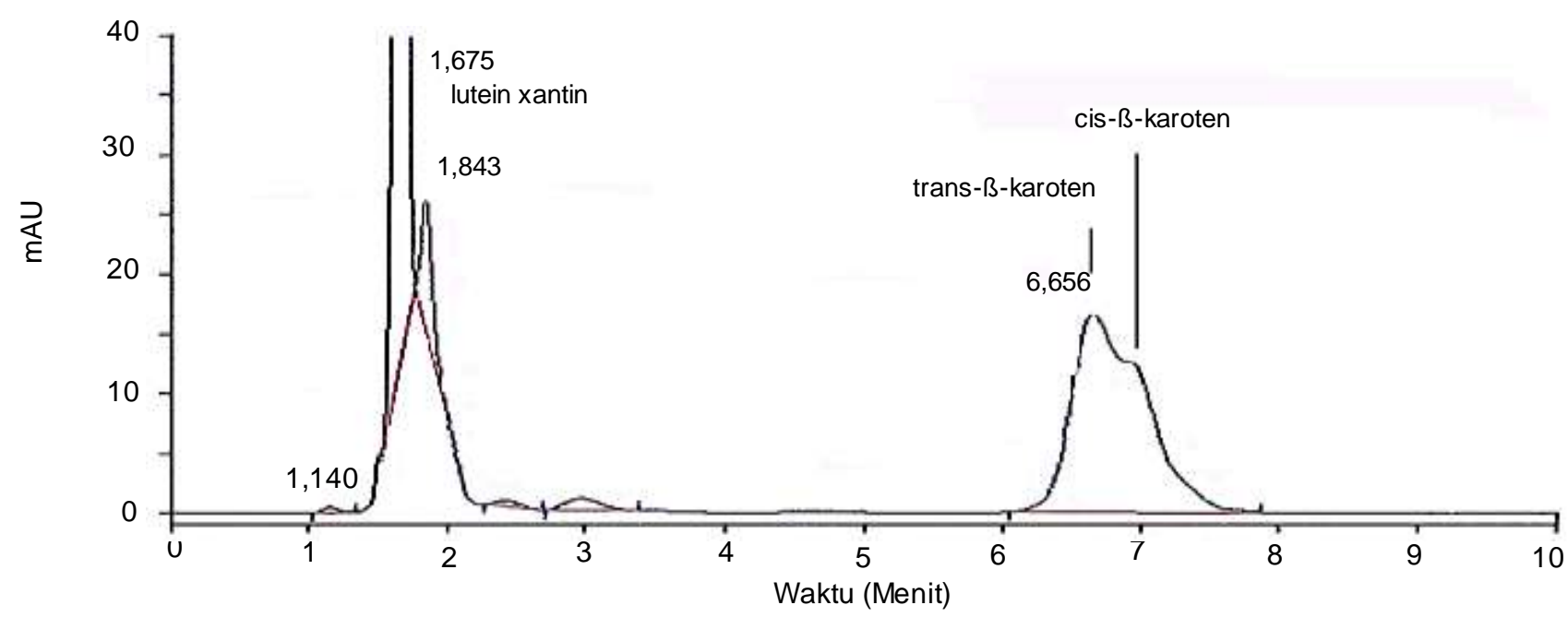

Gambar 12. Kromatogram karotenoid dari produk dengan sari labu kuning $100 \mathrm{~mL}$

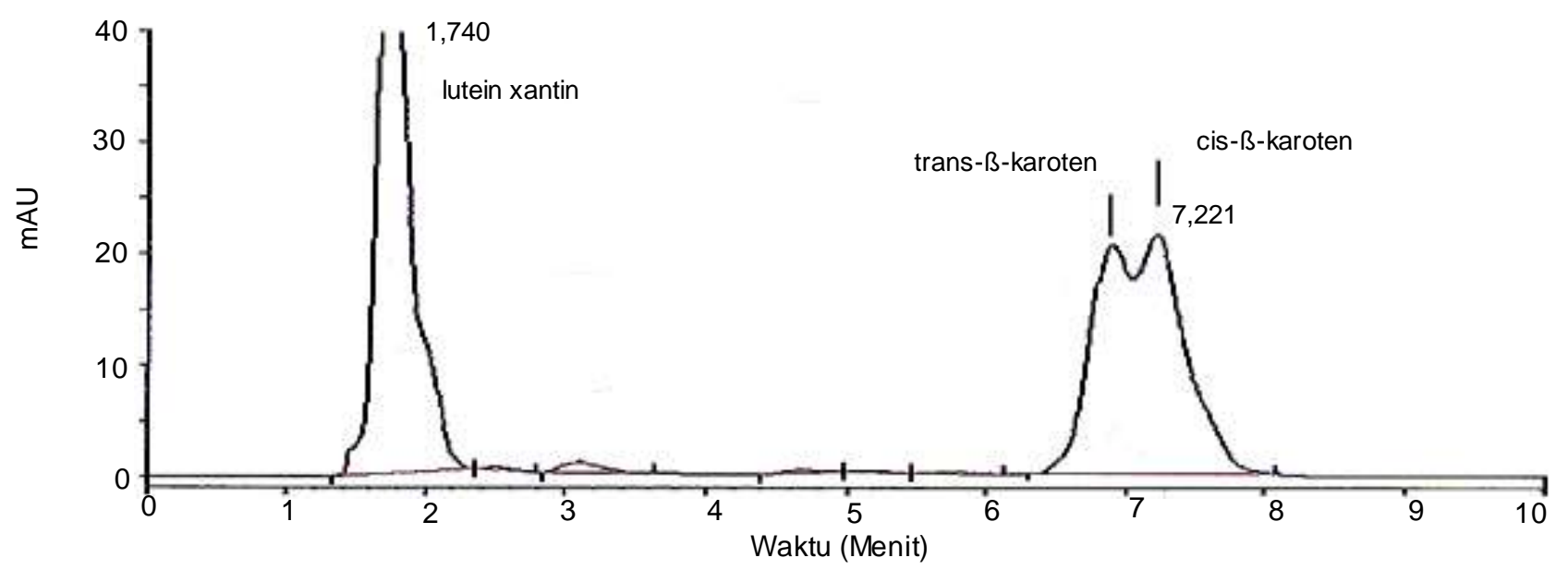

Gambar 13. Kromatogram karotenoid dari produk emulsi sari labu kuning dan FO-MSM 
Senada dengan hasil penelitian ini, Shi et al. (2010) menyatakan suhu dan tekanan mempengaruhi perubahan konfigurasi trans- menjadi cis- $\beta$ karoten, pengolahan dengan suhu yang lebih tinggi menyebabkan penurunan konsentrasi all-trans- $\beta$ karoten berkisar $25-50 \%$ pada peningkatan suhu sebesar $30^{\circ} \mathrm{C}$ dari $40^{\circ} \mathrm{C}$. Shi et al. (2013) menyatakan kadar karotenoid yang terdiri dari lutein, $\alpha$ karoten, dan trans- $\beta$-karoten yang diperoleh menjadi lebih tinggi pada perlakuan suhu rendah, sehingga direkomendasikan suhu pengolahan adalah 50$80^{\circ} \mathrm{C}$. Dari sisi konversi pro-vitamin A menjadi vitamin $A$ di dalam tubuh, keberadaan trans- $\beta$ karoten menjadi penting, karena potensi aktivitas senyawa ini paling tinggi. Jika diukur dengan basis aktivitas trans- $\beta$-karoten $100 \%$, cis- $\beta$-karoten memiliki aktivitas $38-53 \%$, $\alpha$-karoten $53 \%$, $\beta$-cryptoxanthin $57 \%$, dan $\mathrm{Y}$-karoten $42-50 \%$ (Fernandez-Garcia et al., 2012).

Terkait dengan proses pemanasan untuk mengurangi aroma kelapa sawit, penelusuran literatur telah dilakukan untuk menentukan metode pemanasan yang terbaik untuk melindungi kandungan karotenoid dari FO-MSM. Berdasarkan hasil penelitian Rismawati (2009), kandungan karotenoid pada FO-MSM sebelum dipanaskan adalah 494,070 ppm, diukur menggunakan metode Palm Oil Research Institute of Malaysia (PORIM). Wulandari (2000) menggunakan suhu $180^{\circ} \mathrm{C}$ selama 20 menit untuk menghasilkan produk minyak sawit merah dengan kadar karotenoid 249 ppm dan asam lemak bebas $0,2 \%$. Pemanasan pada suhu $160^{\circ} \mathrm{C}$ selama 120 menit di bawah tekanan $15 \mathrm{cmHg}$ menghasilkan minyak sawit merah dengan kandungan karoten 518 ppm dan asam lemak bebas 0,171\%. Pemrosesan pada suhu $160^{\circ} \mathrm{C}$ selama 6 jam di bawah tekanan $60 \mathrm{mmHg}$ menghasilkan kadar karotenoid total FOMSM fraksi olein menjadi 458-600 ppm (Rismawati, 2009). Akan tetapi, kromatogram FO-MSM pasca dipanaskan menunjukkan terdapat perubahan struktur kimiawi $\beta$-karoten dari trans- menjadi cis- $\beta$-karoten yang dibuktikan dalam analisis HPLC (Gambar 11).

\section{Parameter kimiawi}

Produk-produk emulsi sari labu kuning dan FOMSM memiliki kadar asam lemak bebas $<3 \%$ (Tabel
1), masih memenuhi standar yang disyaratkan untuk produk berbasis FO-MSM yaitu kadar asam lemak bebas maksimal 3\% (Mba et al., 2015). Sekalipun FO-MSM mengandung tokotrienol yang dapat berfungsi sebagai antioksidan, dalam pengembangan produk tetap perlu dilakukan penambahan antioksidan yang lain dan mengurangi proses pemanasan tidak perlu yang bertujuan untuk mencegah proses oksidasi asam lemak menjadi asam lemak bebas (Zou dan Akoh, 2015).

Berdasarkan analisis $\mathrm{pH}$ diperoleh bahwa produk pada umumnya bersifat asam dengan nilai rerata $\mathrm{pH} 2,9 \pm 0,1$ untuk kontrol tanpa labu dan FOMSM, 3,5 $\pm 0,1$ untuk sari labu kuning, 3,2 $\pm 0,1$ untuk FO-MSM, dan 3,6 $\pm 0,1$ untuk produk emulsi sari labu kuning dan FO-MSM (90:10v/v) (Tabel 1). Hasil ini selaras dengan persepsi panelis yang menyatakan bahwa semua produk cenderung asam (Gambar 2). Setelah penyimpanan selama dua bulan diperoleh perubahan yang tidak signifikan terhadap $\mathrm{pH}$, yaitu $3,6 \pm 0,1$ untuk kontrol, $2,0 \pm 0,1$ untuk sari labu kuning, 3,2 $\pm 0,1$ untuk FO-MSM, dan 3,6 $\pm 0,1$ untuk produk emulsi. Berkaitan pengembangan produk lebih lanjut dan stabilitas warna selama penyimpanan, dari literatur diketahui bahwa $\mathrm{pH}$ produk emulsi belum berada pada kondisi ideal yang mampu melindungi komposisi karotenoid. Stabilitas warna terbaik untuk produk sari labu adalah pada $\mathrm{pH}$ 4-6 dengan bahan tambahan kalium sorbat dan asam askorbat dapat digunakan sebagai pengontrol $\mathrm{pH}$ produk (Gliemmo et al., 2009).

Kebutuhan akan vitamin $\mathrm{C}$ harian bagi anakanak adalah $45 \mathrm{mg}$, sementara bagi orang dewasa berkisar $90 \mathrm{mg}$. Menurut studi terbaru, kebutuhan akan vitamin $\mathrm{C}$ optimum bagi orang dewasa adalah $200 \mathrm{mg}$ per hari (Frei et al., 2012). Kadar vitamin C selama penyimpanan di ruang berpendingin dengan suhu $8-12^{\circ} \mathrm{C}$ cenderung stabil (Torres et al., 2011) dan disimpan dalam botol berwarna gelap serta tidak terkena cahaya matahari langsung. Dari penelitian tersebut, untuk produk emulsi sari labu kuning dan FO-MSM, kadar vitamin C pasca penyimpanan produk selama dua bulan di suhu rendah diduga tidak mengalami perubahan signifikan.

Tabel 1. Rekapitulasi parameter pengamatan terdiri dari FFA, pH, vitamin C, dan bilangan peroksida

\begin{tabular}{lccccccc}
\hline \multirow{2}{*}{ Produk } & \multicolumn{2}{c}{ Sebelum Penyimpanan } & & \multicolumn{3}{c}{ Setelah Penyimpanan } \\
\cline { 2 - 4 } & FFA (\%) & pH & Vit. C $(\mathrm{mg} / 100 \mathrm{~g})$ & & FFA (\%) & $\mathrm{pH}$ & $\mathrm{PV}(\mathrm{mEq} \mathrm{O} / \mathrm{kg})$ \\
\hline Kontrol (-) & $2,05 \pm 0,06$ & $2,9 \pm 0,1$ & $6,2 \pm 1,2$ & & $1,89 \pm 0,00$ & $3,6 \pm 0,1$ & $0,7 \pm 0,1$ \\
Sari labu kuning & $1,54 \pm 0,04$ & $3,5 \pm 0,1$ & $8,8 \pm 2,5$ & & $1,28 \pm 0,00$ & $2,0 \pm 0,1$ & $0,5 \pm 0,0$ \\
FO-MSM & $2,05 \pm 0,00$ & $3,2 \pm 0,1$ & $24,6 \pm 5,0$ & & $2,39 \pm 0,70$ & $3,2 \pm 0,1$ & $1,3 \pm 0,0$ \\
Produk emulsi & $1,73 \pm 0,06$ & $3,6 \pm 0,1$ & $13,2 \pm 1,2$ & & $1,59 \pm 0,35$ & $3,6 \pm 0,1$ & $0,8 \pm 0,0$ \\
\hline
\end{tabular}

Keterangan: Kontrol (-) = tanpa sari labu kuning dan FO-MSM 
Berdasarkan hasil analisis diperoleh bahwa kadar vitamin $\mathrm{C}$ sebelum penyimpanan dari kontrol adalah $6,2 \pm 1,2 \mathrm{mg} / 100 \mathrm{~g}$ bahan. Produk dengan formula $100 \mathrm{~mL}$ sari labu kuning dan $100 \mathrm{~mL}$ FOMSM masing-masing memiliki kadar vitamin $C$ 8,8 $\pm 2,5 \mathrm{mg} / 100 \mathrm{~g}$ dan 24,6 $\pm 5,0 \mathrm{mg} / 100 \mathrm{~g}$ bahan. Produk emulsi labu kuning dan FO-MSM (90:10v/v) memiliki kandungan vitamin $C$ sebesar 13,2 $\pm 1,2$ $\mathrm{mg} / 100 \mathrm{~g}$ bahan. Berdasarkan hasil analisis terhadap FFA, diperoleh bahwa produk awal emulsi memiliki kadar FFA awal sebesar 1,73 $\pm 0,04 \%$. Setelah disimpan selama dua bulan pada suhu 8$12^{\circ} \mathrm{C}$, tidak terdapat perubahan kadar FFA produk yang signifikan, yaitu $1,59 \pm 0,35 \%$ (Tabel 1 ).

\section{Pengembangan produk lanjutan}

Pengembangan produk lanjutan dari penelitian ini adalah perbaikan proses pemanasan untuk menghilangkan bau khas minyak sawit merah sekaligus mempertahankan struktur trans- $\beta$-karoten, serta pengujian bioavailabilitas dan toksisitas produk. Beberapa teknik yang direkomendasikan untuk mengukur konsentrasi karotenoid, retinol, dan $\alpha$-tokoferol dalam plasma darah adalah metode retinol-binding protein (RBP) and transthyretin (TTR), selain HPLC (Mueller et al., 2007). Pengukuran antioksidan terhadap produk akan dilakukan pada tahap penelitian selanjutnya.

\section{KESIMPULAN}

Produk emulsi labu kuning dan FO-MSM sebagai suplemen pencegahan defisiensi vitamin $A$ dapat diformulasikan dengan komposisi $90 \mathrm{~mL}$ labu kuning dan $10 \mathrm{~mL}$ FO-MSM yang kemudian diencerkan 1:4 (v/v). Karakteristik produk adalah manis, asam, tidak pahit, tidak beraroma mentah, dan tidak beraroma tengik. Secara keseluruhan produk disukai oleh panelis. Proses pemanasan selama lima jam sangat membantu mengurangi aroma khas minyak sawit, sekalipun meningkatkan puncak cis- $\beta$ karoten pada kromatogram. Produk emulsi terpilih memiliki kandungan trans- $\beta$-karoten sebesar 141,65 $\pm 0,47 \mathrm{mg} / \mathrm{L}$ atau setara dengan $237 \mathrm{Ul}$ aktivitas vitamin $\mathrm{A} / \mathrm{mL}$. Produk bersifat asam dengan $\mathrm{pH}$ $3,6 \pm 0,1$ dengan kandungan vitamin $C$ sebesar 13,2 $\mathrm{mg} / 100 \mathrm{~g}$ produk. Keasaman dan kadar vitamin C cenderung tetap selama masa penyimpanan dua bulan. Bilangan peroksida dari produk emulsi adalah 0,8 $\mathrm{mEq}$ oksigen/kg dan bilangan asam lemak bebas berada pada kisaran 1,59-1,73\%, juga tidak mengalami perubahan berarti setelah disimpan selama dua bulan.

\section{UCAPAN TERIMA KASIH}

Tim peneliti mengucapkan terima kasih atas hibah penelitian unggulan strategis PTN/PTS Pemerintah Provinsi Kalimantan Timur tahun pertama. Sebagian dari data (kromatogram formula terpilih, $\mathrm{pH}$, dan FFA) telah dipresentasikan sebagai poster: Sukmiyati Agustin, Miftakhur Rohmah, and Anton Rahmadi. Emulsification of Pumpkin Extract and Red Palm Oil as Functional Food Product Rich In Carotenoids. International Conference on Challenges of Biotechnology in Food and Health. Slamet Riyadi University, Surakarta, Central Java, 15-16 November 2014

\section{DAFTAR PUSTAKA}

[AOAC] Association of Official Analytical Chemist. 2005. Official Method of Analysis of The Association of Official Analysis Chemist. Washington DC (USA): AOAC Inc.

Badr SE, Shaaban M, Elkholy YM, Helal MH, Hamza AS, Masoud MS, El Safty MM. 2011. Chemical composition and biological activity of ripe pumpkin fruits (Cucurbita pepo L.) cultivated in Egyptian habitats. Nat Prod Res 25: 1524-1539. DOI: $10.1080 / 14786410903312991$.

Benn CS, Diness BR, Roth A, Nante E, Fisker AB, Lisse IM, Yazdanbakhsh $M$, Whittle $H$, Rodrigues A, Aaby P. 2008. Effect of 50.000 IU vitamin A given with BCG vaccine mortality in infants in Guinea-Bissau: randomised placebo controlled trial. BMJ Online First 336: 1-9 DOI: 10.1136/bmj.39542.509444.AE.

Fernandez-Garcia E, Carvajal-Lerida I, Jaren-Galan M, Garrido-Fernandez J, Perez-Galvez A, Hornero-Mendez D. 2012. Carotenoids bioavailability from foods: From plant pigments to efficient biological activities. Food Res Int 46: 438-450. DOI: 10.1016/j.foodres.2011.06.007.

Firdous AP, Preethi KC, Kuttan R. 2010. Antioxidant potential of meso-zeaxanthin a semi synthetic carotenoid. Food Chem 119: 1096-1101. DOI: 10.1016/j.foodchem.2009.08.021.

Frei B, Birlouez-Aragon I, Lykkesfeldt J. 2012. Authors' perspective: what is the optimum intake of vitamin $C$ in humans ?. Crit Rev Food Sci 52: 815-829. DOI: 10.1080/10408398.2011. 649149.

Gliemmo MF, Latorre ME, Gerschenson LN, Campos CA. 2009. Color stability of pumpkin (Cucurbita moschata, Duchesne ex Poiret) puree during storage at room temperature: Effect of $\mathrm{pH}$, potassium sorbate, ascorbic acid 
and packaging material. LWT-Food Sci Technol 42: 196-201. DOI: 10.1016/j.Iwt. 2008.05.011.

Goncalves EM, Pinheiro J, Abreu M, Brandao TRS, Silava CLM. 2007. Modelling the kinetics of peroxidase inactivation, colour and texture changes of pumpkin (Cucurbita maxima L.) during blanching. J Food Eng 81: 693-701. DOI: 10.1016/j.jfoodeng.2007.01.011.

Groeber U. 2013. Mikronutrien: Penyelarasan Metabolik, Pencegahan, dan Terapi. Penerbit Buku Kedokteran EGC, Jakarta.

Jacobo-Valenzuela, N, Zazueta-Morales JDJ, Gallegos-Infante, JA, Aguilar-Gutierrez, J, CamachoHernández, IL, Rocha-Guzman, NL, GonzalezLaredo, RF. 2011 a. Chemical and physicochemical characterization of winter squash (Cucurbita moschata D.) Not Bot Horti Agrobo 39: 34-40.

Jacobo-Valenzuela N, Marostica-Junior M, ZazuetaMorales JJ, Gallegos-Infante JA. 2011 ${ }^{\mathrm{b}}$. Physicochemical, technological properties, and health-benefits of Cucurbita moschata Duchense vs. Cehualca: A review. Food Res Int 44: 2587-2593. DOI: 10.1016/j.foodres.2011. 04.039.

Jaswir I, Noviendri D, Hasrini RF, Octavianti F. 2011. Carotenoids: sources, medicinal properties and their application in food and nutraceutical industry. J Med Plants Res 5: 7119-7131.

Konopacka D, Seroczynska A, Korozeniewska A, Jesionkowska K, Niemirowicz-Szcytt K, Plocharski W. 2010. Studies on the usefulness of Cucurbita maxima for the production of ready-to-eat dried vegetable snacks with a high carotenoid content. LWT-Food Sci Technol 43: 302-309. DOI: 10.1016/ j.Iwt.2009.08.012.

Mba OI, Dumont MJ, Ngadi M. 2015. Palm oil: Processing, characterization and utilization in the food industry - A review. Food Biosci 10: 26-41. DOI: 10.1016/j.fbio.2015.01.003.

Montenegro L, Rapisarda L, Ministeri C, Pugilisi C. 2015. Effects of lipids and emulsifiers on the physicochemical and sensory properties of cosmetic emulsions containing vitamin $E$ Cosmetics 2: 35-47. DOI: 10.3390/cosmetics 2010035.

Mueller K, Voigt CC, Raila J, Hurtienne A, Vater M, Brunnberg L, Schweigert FJ. 2007. Concentration of carotenoids, retinol and $\alpha$-tocopherol in plasma of six microchiroptera species. Comp Biochem Phy B 147: 492-497. DOI: 10.1016/j. cbpb.2007.03.002.

Oxley A, Berry P, Taylor GA, Cowell J, Hall MJ, Hesketh J, Lietz G, Boddy AV. 2014. An
LC/MS/MS method for stable isotope dilution studies of $\beta$-carotene bioavailability, bioconversion, and vitamin A status in humans. J Lipid Res 55: 319-328. DOI: 10.1194/jlr.D040204.

Provesi JG, Dias CO, Amante ER. 2011. Changes in carotenoids during processing and storage of pumpkin puree. Food Chem 128: 195-202. DOI: 10.1016/j.foodchem.2011.03.027.

Rahmadi A, Agustin, S, Rohmah, M. 2014. Produk Olahan Emulsi Labu dan Minyak Sawit untuk Intervensi Balita Kurang Vitamin A di Kalimantan Timur. Laporan Hasil Penelitian Unggulan PTN/PTS Pemerintah Propinsi Kalimantan Timur, Samarinda.

Rao AV, Rao LG. 2007. Carotenoids and human health. Pharmacolo Res 55: 207-216.

Rismawati. 2009. Pengaruh Waktu Deodorisasi Terhadap Olein dan Stearin Minyak Sawit Merah serta Aplikasinya Sebagai Medium Penggorengan Tempe dan Ubi Jalar Putih. [Skripsi]. Bogor: Fakultas Teknologi Pertanian, Institut Pertanian Bogor.

Sattar S, Ahmed T, Rasul CH, Saha D, Abdus Salam M, Hossain MI. 2012. Efficacy of a HighDose in Addition to Daily Low-Dose Vitamin A in Children Suffering from Severe Acute Malnutrition with Other IIInesses. PLOS one 7: e33112. DOI: 10.1371/journal.pone. 0033112.

Schieber A, Carle R. 2005. Occurrence of carotenoid cis-isomers in food: technological, analytical, and nutritional implications. Trends Food Sci Tech 16: 416-422. DOI: 10.1016/j. tifs.2005.03.018.

Sepp T, Karu U, Sild E, Maenniste M, Hourak P. 2011. Effects of carotenoids, immune activation and immune suppression on the intensity of chronic coccidiosis in green-finches. Exp Parasitol 127: 651-657. DOI: 10.1016/j.exppara. 2010.12.004.

Setyahartini S. 1994. Identifikasi Senyawa Karoten pada Labu Merah (Cucurbita moschata). Makalah Seminar Bulanan Jurusan Budidaya Pertanian, Fakultas Pertanian, Universitas Mulawarman.

Shi J, Yi C, Ye X, Xue S, Jiang Y, Ma Y, Liu D. 2010. Effects of supercritical $\mathrm{CO}_{2}$ fluid parameters on chemical composition and yield of carotenoids extracted from pumpkin. LWTFood Sci Technol 43: 39-44. DOI: 10.1016/j. Iwt.2009.07.003.

Shi X, Wu H, Shi J, Xue SJ, Wang D, Wang W, Cheng A, Gong Z, Chen X, Wang C. 2013. Effect of modifier on the composition and antioxidant activity of carotenoid extracts from pumpkin (Cucurbita maxima) by supercritical 
$\mathrm{CO}_{2}$. LWT-Food Sci Technol 51: 433-440. DOI: 10.1016/j.Iwt.2012.11.003.

Sudarmadji S, Haryono B, Suhardi. 2003. Analisis Bahan Makanan dan Pertanian. Penerbit Liberty, Yogyakarta.

Tadmor Y, Paris HS, Meir A, Schaffer AA, Lewinsohn E. 2005. Dual role of the pigmentation gene $B$ in affecting carotenoid and vitamin $\mathrm{E}$ content in squash (Cucurbita pepo) mesocarp. J Agr Food Chem 53: 9759-9763. DOI: $10.1021 /$ jf0520591.

Tang FY. 2012. The silver bullet for cancer prevention: Chemopreventive effects of carotenoids. BioMedicine 2: 117-121. DOI: 10.1016/j. biomed.2012.06.004.

Torres B, Tiwari BK, Patras A, Cullen PJ, Brunton N, O'Donnel CP. 2011. Stability of anthocyanins and ascorbic acid of high pressure processed blood orange juice during storage. Innov Food Sci Emerg 12: 93-97. DOI: 10.1016/j.ifset.2011. 01.005.
USDA [United States Department of Agriculture]. 2014. Nutrient data for: 0405 - oil, palm and 11422 - Pumpkin, raw. USDA national nutrient database for standard reference 27 Software v.2.0b http://ndb.nal.usda.gov/ndb/foods/ [14 Oktober 2014].

Vaisman N, Haenen GRMM, Zaruk Y, Yerduyn C, Bindels JG, Verlaan S, Meijer EP. 2006. Enteral feeding enriched with carotenoids normalizes the carotenoid status and reduces oxidative stress in long-term enterally fed patients. Clin Nutr 25: 897-905. DOI: 10.1016/j.clnu.2006.06. 002.

Wulandari OV. 2000. Pemanfaatan Minyak Sawit untuk Produksi Emulsi Kaya Beta-Karoten Sebagai Suplemen Vitamin A. [Skripsi]. Bogor: Jurusan Teknologi Pangan dan Gizi, Fateta, Institut Pertanian Bogor.

Zou L, Akoh CC. 2015. Antioxidant activities of annatto and palm tocotrienol-rich fractions in fish oil and structured lipid-based infant formula emulsion. Food Chem 168: 504-511. DOI: 10.1016/j.foodchem.2014.07.098. 